\title{
Pussyfooting around the issue of cat predation in urban areas
}

\author{
YOLANDA VAN HEEZIK
}

In an earlier editorial Adams (2007) argued for the integration of social science and conservation, despite differences in language and terminology and in traditions of enquiry and methodologies. He emphasized that conservation biologists need to think in an interdisciplinary way to make progress. Nowhere is this more evident than in the fledgling discipline of urban ecology.

MacDonnell \& Pickett (1990) described urbanization as 'a massive unplanned experiment', providing ecologists with opportunities to answer questions of general applicability as well as those specific to the impacts of urbanization. The study of biodiversity and ecosystem function in urban areas is now an expanding discipline that poses many challenges. For ecologists these challenges lie in developing an understanding of how these highly modified systems function and respond to urbanization but for conservation biologists the challenges lie primarily in understanding and influencing human attitudes, interests and motivations.

Humans are both the problem and the solution in urban landscapes. The structure of this environment and its ability to support biodiversity is the integrated outcome of both top-down (city-level management strategies and decisions) and bottom-up human influences (choices or actions by householders and individuals; Kinzig et al., 2005). Largescale changes benefiting biodiversity can potentially be achieved through bottom-up influences if city dwellers are motivated to recognize and appreciate native species and feel they can make a contribution to enhancing biodiversity. This could involve planting more native trees and shrubs in their gardens, creating habitat, not keeping a cat (or keeping it inside) or using fewer pesticides, but it could also involve putting pressure on local government to take a proactive approach to enhancing urban biodiversity.

The value of engaging city dwellers in biodiversity issues is multifaceted. Regular encounters with nature improve human well-being and opportunities to experience nature within the urban environment are thus important to us. With most people now living in urban areas, often with limited access to natural areas and native wildlife, people have become disconnected from nature (Pyle, 2003; Miller, 2005) and are consequently less likely to support conservation initiatives at personal and political levels (Dunn et al., 2006). Paradoxically, conservation of biodiversity in both modified and unmodified landscapes may increasingly depend on the ability of city dwellers to maintain a personal connection with nature (Dunn et al., 2006). Motivations for conserving urban biodiversity therefore range from benefits to nature (e.g. preservation of biodiversity and creation of stepping stones or corridors) to benefits to humans: e.g. the provision of ecosystem services, connecting people with nature, improving human well-being and fulfilling ethical responsibilities (Dearborn \& Kark, in press). Conservation biologists working in urban areas require not only an understanding of the cultural, psychological and socioeconomic drivers that shape peoples' attitudes and motivations but also an appreciation of how these can be changed-this requires real inter-disciplinary thinking.

One of the greatest impediments to urban biodiversity conservation, and a problem that exemplifies the necessity for inter-disciplinary thinking, is the domestic cat. Cats are highly valued as companions and can provide health benefits to their owners. Cat ownership is deeply entrenched within Western society and in most countries cat owners are not subject to the regulations imposed on dog owners. Generally there is no limit to the number of cats people can own and cats are usually free to roam. Studies conducted in the UK, USA, Australia and New Zealand (Barratt, 1998; Baker et al., 2008; van Heezik et al., 2010) confirm that domestic cats are significant predators of city wildlife. As subsidized predators, domestic cats can exert pressure on prey populations even when prey are reduced to low densities. With cat ownership at c. $35 \%$ of households and densities of $200-1,580 \mathrm{~km}^{-2}$ (summarized by van Heezik et al., 2010) the urban landscape is saturated with cats, and although not all are active hunters their densities are so great and their home ranges so flexible that their presence is felt virtually everywhere.

Ways to reduce cat catch, such as belled collars, collars with sonic devices, sonar deterrents and cat bibs, have been examined. Although some reduce predation, none eliminate it. Guidelines for reducing predation by cats are often ad hoc, baseless and feeble: for example, feeding your cat well so it is less likely to hunt (a fallacy), micro-chipping to identify it as a pet rather than a stray (as if a skink cares who eats it) or night curfews (which don't protect diurnal species such as birds and reptiles). The domestic cat population also maintains the feral cat population, as cats are abandoned by irresponsible owners, and the growing trend for ill-informed and soft-hearted urban dwellers to oppose cat control and advocate trap-neuter-return programmes exacerbates the feral cat problem (Lepczyk et al., in press). Society needs to ask what it wants in its environment-wildlife or cats-and the job of conservation biologists is to make sure that the informed answer is wildlife. Currently, conservation biologists are pussyfooting around this problem, content to document the impacts but not tackling the human 
dimensions, and hesitating to be more active in raising the issue at a political level.

The problem is clearly social but most of the research about impacts of cats has not addressed social issues. Australia seems to be the only country where research on impacts of domestic cats includes surveys to determine public opinion on whether cats pose a threat to wildlife and public support for different control measures (Grayson \& Calver, 2004). Some local councils in Australia have implemented mitigation measures such as cat confinement and no-cat zones. However, these local regulations have not been accompanied by rigorous monitoring of the efficacy of the different measures. In New Zealand, where great effort is directed at controlling introduced predators in reserves and national parks, domestic cats remain completely under the radar, possibly because environmental management follows a preservation model involving the protection of wilderness areas and threatened species, with little value ascribed to modified habitats. There are few laws or regulations in place in New Zealand to restrict cat behaviour or penalize cat owners. Some new sub-divisions are cat-free but there has been no research into whether there are any beneficial effects for wildlife. The possibility that cats may suppress rat populations in a meso-predator effect is a complicating factor. It is these nuances that demand collaborations of social scientists, ecologists and psychologists.

Domestic cats elicit strong emotions and these are likely to lead to conflict. As awareness about biodiversity develops among urban residents a growing number of people who have created wildlife-friendly environments in their backyards are becoming frustrated that their efforts are undermined by the activities of neighbours' cats. Translocations of native species into suitable urban habitat are not an option if predators remain a problem. Concerns about welfare of cats have been used in Australia to encourage cat owners to restrict their cats to indoors or cat runs, and a small number of well-informed people are taking the necessary precautions to prevent their cats from encountering wildlife. The problem is that the majority of city inhabitants are neither well-informed nor have any real appreciation of native wildlife.

Twenty years ago Gilbert (1989) wrote 'The fostering of wildlife areas in cities is too complex an operation to be left in the hands of the ecologists', and this is still the case. Most ecologists lack the skills to address the challenges, which lie in the realms of social science and psychology, necessitating multi-disciplinary partnerships between social scientists, psychologists, geographers and ecologists (Bowman \& Marzluff, 2001). It is difficult to step outside one's own discipline and appreciate the validity of alternative methodologies, perspectives and philosophies. However, prog- ress in conservation of biodiversity in urban landscapes depends on our willingness to do this.

Yolanda VAN HEEZIK Department of Zoology, University of Otago, P.O. Box 56, Dunedin, 9050, New Zealand.

E-mail yolanda.vanheezik@stonebow.otago.ac.nz

\section{References}

Adams, W.M. (2007) Thinking like a human: social science and the two cultures problem. Oryx, 41, 275-276.

Baker, P.J., Molony, S.E., Stone, E., Cuthill, I.C. \& Harris, S. (2008) Cats about town: is predation by free-ranging pet cats Felis catus likely to affect urban bird populations? Ibis, 150 (Suppl. 1), 86-99.

Barratt, D.G. (1998) Predation by house cats, Felis catus (L.), in Canberra, Australia. II. Factors affecting the amount of prey caught and estimates of the impact on wildlife. Wildife Research, 25, 475-487.

Bowman, R. \& Marzluff, J.M. (2001) Integrating avian ecology into emerging paradigms in urban ecology. In Avian Ecology and Conservation in an Urbanizing World (eds J.M. Marzluff, R. Bowman \& R. Donnelly), pp. 569-579. Kluwer Academic Publishers, Boston, USA.

DeARBorn, D.C. \& KARK, S. (in press) Motivations for conserving urban biodiversity. Conservation Biology, DOI: 10.111/j.15231739.2009.01328.x.

Dunn, R.R., Gavin, M.C., SAnchez, M.C. \& Solomon, J.N. (2006) The pigeon paradox: dependence of global conservation on urban nature. Conservation Biology, 20, 1814-1816.

Gilbert, O.L. (1989) The Ecology of Urban Habitats. Chapman and Hall, London, UK.

Grayson, J. \& Calver, M. (2004) Regulation of domestic cat ownership to protect urban wildlife: a justification based on the precautionary principle. In Urban Wildlife: More than Meets the Eye (eds D. Lunney \& S. Burgin), pp 169-178. Royal Zoological Society of New South Wales, Mosman, Australia.

Kinzig, A.P., Warren, P., Martin, C., Hope, D. \& Katti, M. (2005) The effects of human socio-economic status and cultural characteristics on urban patterns of biodiversity. Ecology and Society, 10(1), 23 [http://www.ecologyandsociety.org/volio/iss1/ art23/, accessed 1 March 2010].

Lepczyk, C.A., Dauphiné, N., Bird, D.M., Conant, S., Cooper, R.J., Duffy, D.C., et al. (in press) What conservation biologists can do to counter trap-neuter-return: response to Longcore, et al. Conservation Biology, DOI: 10.1111.j.1523-1739.2009.01426.x.

Macdonnell, M.J. \& Pickett, S.T.A. (1990) Ecosystem structure and function along urban-rural gradients: an unexpected opportunity for ecology. Ecology, 71, 1232-1237.

Miller, J.R. (2005) Biodiversity conservation and the extinction of experience. Trends in Ecology \& Evolution, 20, 430-434.

PyLE, R.M. (2003) Nature matrix: reconnecting people and nature. Oryx, 37, 206-214.

van Heezik, Y., Smyth, A., Adams, A. \& Gordon, J. (2010) Do domestic cats impose an unsustainable harvest on urban bird populations? Biological Conservation, 143, 121-130. 